\title{
Development of the System of Strategic Management of Enterprise on the Basis of Realization of Potential of Integrated Entity
}

Orlov I.U.

Kazan Federal University, Institute of Management, Economics and Finance, Kazan, 420008, Russia

Bagautdinova N.G.

Kazan Federal University, Institute of Management, Economics and Finance, Kazan, 420008, Russia

Pratchenko O.V.

Kazan Federal University, Institute of Language, 420008, Kazan, Russia

\section{Doi:10.5901/mjss.2015.v6n3p856}

\begin{abstract}
The article analyses and gives ground for the mechanism of improvement of processes of the strategic management of integrated entities on the basis of realization of their potential, which allowed to develop guidelines and practical suggestions for rational planning, organization, control and regulation of strategic management of integrated entity. The authors studied and completed the conceptual framework of strategic management of development of integrated entities; the classification of types of corporations is formed; the model of balanced corporate management of integrated entities on the basis of realization of their potential is offered.
\end{abstract}

Keywords: strategic management, integrated entity, competitive strategies, potential of integrated entity, model of balanced corporate management.

\section{Introduction}

In the long-term period the efficiency improvement of development of integrated entities requires the comprehensive restructuring or improvement of processes of strategic management of integrated entities within the concept of corporate management, which will allow to take into account the high level of turbulence of the environment of economic entities and to create a foundation of formation of long-term competitive advantage; it will allow to take into account the interests of internal customers of enterprise and its owners and to ensure the viability of enterprise in the long-term period. In this case, the rational balanced development of potential of integrated entity should be the target of organization management, which, in turn, will ensure the growth of efficiency of use of limited resources and on its basis - the formation of a strategic competitive advantage. Thus, the platform of sustainable development will be formed with rational organization of strategic management of integrated entities on the basis of realization of their potential and formation of associated synergistic determined by efficiency improvement of management, and it will allow to achieve the strategic goals of Russian economy.

These circumstances confirm that today the problem of formation of the rational system of strategic management of integrated entities on the basis of realization of their potential is relevant as far as it allows to solve the important economic problem: to ensure positive translational dynamics of development of economic entities.

Leading foreign economists A. Berle and G. Means are considered to be the founders of corporate management, although a number of classical economists highlighted this aspect of the economics as well - P. Drucker, J. Lambin, A. Marshall, W. Eucken, M. Porter, P. Samuelson, E. Chamberlin. [3, 8, 9, 11]. Theoretical approaches to the development and implementation of strategies of integrated entities are presented in the works of P. Maskell, M. Larenzen, M. Porter, S. Rosenfeld, M. Storper, M. Enright and others. [1, 2, 4, 5, 6, 7, 10, 12].

These circumstances confirm that today the problem of formation of the rational system of strategic management of integrated entities on the basis of realization of their potential is relevant as far as it allows to solve the important economic problem: to ensure positive translational dynamics of development of economic entities. It defined goals, objectives and structure of the study. 


\section{Methodology}

As the analysis of the reasons of the global economic crisis conducted the study, shows, the crisis is largely caused by practice of unsustainable methods and mechanisms of management. Change of the management system, the targeted goal of which should be to ensure not the growth of key indicators of development relative to similar competitors - but the cooperative interaction of all structures of the economic area, is the main way out of it. Use of potential of formed in the result of implementation of the strategy of integrated entities will allow to ensure the qualitative change of dynamics of socio-economic and innovative development of the country on condition of application of modified instruments and mechanisms of corporate management in management processes by such entities. The study showed that the corporate management can be considered in three functional capacities: as an organizational model, with the help of which the company protects and represents the interests of its owners (the concept of "partners"); as a way to improve performance efficiency, to analyze the results, to adjust and achieve the goals (the concept of capital value of shareholders); as the system of management and control of the enterprise performance (the concept of enterprise management). The revealed structure of the concept content allows to determine corporate management of integrated entities as a set of actions aimed at ensuring the interests of financial (shareholders and creditors) and non-financial (employees, state, enterprises partners and others) investors that are beneficiaries of integrated entities. This definition is based on the priority of goals set by owners of business, in the process of achievement of which different conflicts of interests of its participants and partners appear. As a consequence, formation of the system of relations, ways of interaction, the complex of measures and rules, actions that are able to neutralize (minimize) the negative impact and to maintain the positive influence of conflicts of interests of participants and partners to meet the needs of the parties that determine the activities of integrated entity, and business development, becomes the main task. In addition to the application of the proposed approach it is also necessary to focus the attention on the use of synergetic effect in processes of co-operation of all participants of the economic process. These circumstances allowed to present the above interpretation of the concept "corporate management", in which the necessity of using the potential of elements of corporate entity is justified.

The study of influence of financial and non-financial factors of strategic impact on the system of corporate management confirmed the irrational character of one-factor approach in classification of types of corporate management, which necessitates the use of the multifactorial approach to the classification of types of corporate management.

The content analysis of strategic corporate management of integrated entities made it possible to determine that the ratio of concentration of share capital (concentrated or atomistic) and distribution of tools of control by the spheres of responsibility of managers and owners are the key criteria that determine the content of corporate management.

\section{Results}

According to the state of corporate management it is possible to highlight - by selected parameters - the following types of corporations as control objects:

- Corporation of mixed type which is characterized by concentration of shares of owners of enterprises, while the control is the sphere of responsibility of managers;

- Corporation of the traditional type which is characterized by the concentration of shares and control tools in the hands of owners of the enterprise;

- Corporation of stake-holders type which is characterized by distribution of property rights among a large number of participants, so the influence of trade unions and employees, as well as consumers, increases, whereas the control remains the sphere of responsibility of managers;

- Corporation of the privileged type which is also characterized by dispersion of property rights among many participants, while the control over the corporation performance is carried out by an external owner, for example, a major investor;

- Corporation of integration type which involves uniform distribution of shares among the participants of corporate entity, as well as providing the reasonable combination of strategic control by the owners and operational control by professional managers.

This classification of corporation types will allow to form the rational structure of organization of management of integrated entities due to the formation of efficient ratio of powers and responsibilities of owners and management of integrated entities.

Analysis of key trends of development of corporations of different types revealed that the high level of control and balance is typical of corporations of the integrational type, the management system of which is based on balance of 
property and control of activities among the owners and management. This trend is due to the fact that with the parity of concentration of property and control instruments and regulation the concernment of participants of an integrated entity is not limited to the maximization of profits and the development of a single enterprise, but it is also focused on social welfare of partners of integration associations, as far as it increases the value of shares /stocks of other enterprises owned by a particular participant of the association. In this model, building-up of long-term partnership relations of participants of the integration entity is a priority of strategic management which involves improvement of the existing model of corporate management.

The current model of Russian corporate management can be defined as a public corporation, the peculiar feature of which is the expansion of cooperation with investors, government and other corporations, as well as focusing of the attention on the organization of inter-holding management. In this case, inter-holding management should be implemented on the basis of formation of the management organization that will ensure the implementation of the principle of balance of corporate management. This approach to the organization of management of integrated companies will ensure the formation of synergetic effect which appears in the result of reduction of the share of unforced errors of the strategic management in implementation of the main, auxiliary and administrative processes.

Implementation of the proposed approach to corporate management assumes that the created management company will be the organizational-economic center of management in the holding company which is responsible for development of goals and direction of operation and development of integrated the entity as a whole, determination of means, forms and methods in order to achieve these goals, and as the implementation of functions of control and coordination in management. It will allow to ensure consistency, interconnection and effective interaction of subsidiaries which are elements of an integrated entity, on the basis of use of core competencies of corporation in the frames of implementation of the selected strategy of development of enterprise. The performance of the management company concerning business entities is greatly determined by the potential of both the management company itself and the potential of enterprises under its coordination, and - as a consequence - by the degree of achievement of goals set the management company by owners of controlled companies.

In modern conditions the ensuring of the effectiveness and quality of development and implementation of the development strategy of integrated entity should be based on implementation of its strategic potential, the effective use of which will allow to implement the transformation of an economic entity from the current state into the desired one, as well as to implement the rational management of its further performance and development in conditions of a challenging uncertain external environment. In this context, the strategic potential is a system of possibilities of effective application of technical-scientific, human, technological, financial-economic, informational and administrative resources of an integrated unity which ensure the implementation of the chosen strategy by management of changes of internal and external environment of the enterprise. In the frames of this system the organizational and managerial potential of the management company of an integrated entity containing a significant reserve of efficiency improvement of the corporation performance, plays a significant role. Assessment of this potential should include - in addition to the effective component (including the financial one) - the diagnostics of the administrative, business, cooperative activities. These functional characteristics determine the quality of management of an integrated entity, in connection with this the organizational and managerial potential of management company - the ability of a company to ensure the effectiveness, the order in organizational processes, creation of vision, perspective and atmosphere which favor the strategic development.

In conditions of contraction of the resource base of development the large and medium-sized economic entities face the dilemma of integration or re-integration of resources and capabilities in order to improve efficient performance. Implementation of integrational process, on the one hand, reduces the flexibility of socio-economic system and its management due to the complexity of administrative processes, and, on the other hand, allows to react to the increasing complexity of consumer preferences more effectively, which rises tough conditions on coordination at all stages of the life cycle. Integration results are shown not only in reduction of transaction costs, in increase of production profitability, but also in improving competitiveness of business, primarily through the consolidation of efforts of some companies in the market competition, in concentration of resources, the restriction of the level of competition and reduction of internal costs.

Thus, it is necessary to determine the level of strategic potential of an integrated entity in order to solve the problem of effective management of strategic development of it. Taking into account the processes of integration and the role of the management company, we can conclude that the potential of an integrated entity (holding) is a system of strategic potentials of member companies, adjusted for organizational and managerial potential of the management company (MC) and the integration potential of the holding, the implementation of which allows to create a positive synergetic effect.

Algorithm of the assessment of the potential of integrated entity includes the assessment of the strategic potential 
of an integrated structure, in the frames of which the calculated indicators and the expert assessment of capacity of an integrated entity are determined by the type of resources in the structure of the strategic potential. Integral estimate (the ratio of the desired value to the value of the indicator) of strategic potential is the result of calculations. Then the evaluation of the organizational and managerial potential of the MC that ensures the coefficients of strategic development, production activities (as well as commercial activities or the services), finance, administration and cooperation is carried out. Based on the assessment of particular indicators of the integration capacity of the holding, within a matrix evaluation of the integration potential of the holding (Fig. 1) in which the coefficients are calculated competence $(\Sigma \mathrm{a} / \mathrm{n})$ and concentration $(\Sigma \mathrm{f} / \mathrm{m})$, is formed. Assessment of integration potential of the holding implemented on the basis of the matrix of evaluation of integration potential of holding (Fig. 1), in which the coefficients of competence $\left(\sum \mathrm{a} / \mathrm{n}\right)$ and concentration $\left(\left(\sum \mathrm{f} / \mathrm{m}\right)\right.$ are calculated, is formed on the basis of the particular indicators obtained.

\begin{tabular}{|c|c|c|c|c|c|c|}
\hline & \multicolumn{4}{|c|}{ Integrated structures } & \multirow[b]{2}{*}{$\sum \mathrm{a}$} \\
\hline & & A1 & A2 & A3 & $A m-1$ & \\
\hline \multirow{4}{*}{ 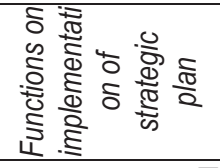 } & F1 & & & & & \\
\hline & $\mathrm{F} 2$ & & & & & \\
\hline & F3 & & & & & \\
\hline & Fn-1 & & & & & \\
\hline \multicolumn{2}{|c|}{$\sum f$} & & & & & \\
\hline
\end{tabular}

Fig. 1. Assessment matrix of integration potential of holding ${ }^{1}$

Evaluation of components of the strategic potential of an integrated entity (holding) conducted by this algorithm should be used when choosing the development strategy of the business entity.

Effective implementation of the strategy of development of an integrated entity should be based on application of tools of strategic goal setting, on development of criteria of selection of strategy development, validity of priority of the strategy; as a whole it will allow to form conditions for the rational use of potential of integrated entity. Absolute transparency of strategic initiatives for internal and external partners of integrated entity should be also provided in the implementation of the strategy; it will reduce wasteful expenditures of the holding to ensure development and to prevent irrational decisions of owners and potential owners concerning the future value of shares of integrated entity.

Timely and informed choice of development strategy of the organization is a dispensable condition to ensure the development of business in a dynamic changing environment in the long-term period. In the process of selection and further working out of the strategy of development if integrated entity it is necessary to highlight the strategy of cooperation and the strategy of competitive integration, with the organizational capacity of the management company and the integral level of the strategic potential of the company as parts of the corporate entity in the basis of the classification of which (Fig. 2).

\begin{tabular}{|c|c|c|c|c|}
\hline Integration & $\begin{array}{c}\text { Organizational and managerial } \\
\text { potential of the management company }\end{array}$ & $\begin{array}{c}\text { Integral level of } \\
\text { strategic potential of } \\
\text { the company }\end{array}$ & \multicolumn{2}{|c|}{ Types of strategy } \\
\hline \multirow{4}{*}{$\begin{array}{l}\text { Presence of } \\
\text { integration potential }\end{array}$} & \multirow{2}{*}{$\geq 2,5$} & $\geq 8,5$ & Networking strategy & \multirow{4}{*}{ 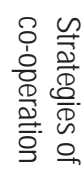 } \\
\hline & & $<8,5$ & Stellar strategy & \\
\hline & \multirow[b]{2}{*}{$<2,5$} & $\geq 8,5$ & Agent strategy & \\
\hline & & $<8,5$ & $\begin{array}{l}\text { Strategy of random } \\
\text { partner }\end{array}$ & \\
\hline \multirow{4}{*}{$\begin{array}{c}\text { Absence of } \\
\text { integration potential }\end{array}$} & \multirow[b]{2}{*}{$\geq 2,5$} & $\geq 8,5$ & Innovational strategy & \multirow{4}{*}{ 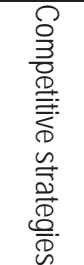 } \\
\hline & & $<8,5$ & $\begin{array}{l}\text { Leader following } \\
\text { strategy }\end{array}$ & \\
\hline & \multirow{2}{*}{$<2,5$} & $\geq 8,5$ & $\begin{array}{l}\text { Strategy of focused } \\
\text { specialization }\end{array}$ & \\
\hline & & $<8,5$ & $\begin{array}{l}\text { Strategy of } \\
\text { adaptation }\end{array}$ & \\
\hline
\end{tabular}

Fig. 2. Matrix of selection of the development strategy of integrated entity

${ }_{1}^{1}$ where $n$ - number of functions; $m$ - number of integrated structures; $F$ - functions of strategic planning; $A$ - integrated structure. 
Threshold values can be changed depending on comprehensive potential characteristics required for the strategic development. Implementation of the proposed approach to the selection of the development strategy of integrated entity will allow to form conditions for its effective implementation due to the account of the level of potential of the elements of the integrated company and their adjustment to the level of the organizational and managerial capacity of the management company, the implementation of which allows to create the positive synergetic effect.

\section{Conclusion}

The study allowed to draw the following conclusions:

1. Rational strategic management of development of integrated entity on the basis of realization of its potential should be based on refined understanding of corporate management of an integrated entity which is interpreted as a set of actions aimed at ensuring the interests of financial and non-financial investors.

2. Development strategy of integrated entity (corporation) involves the use of two-parameter classification of types of integrated corporate entities that will allow to improve the process of development of the strategic management system.

3. Rational management of the strategic development of integrated entity should be based on application of the model of balanced corporate management of integrated entities adapted to the requirements of strategic management.

4. Implementation of processes of strategic management of integrated entities on the basis on the rational use of their potential involves the application of algorithm of estimation of integration potential of the holding based on definition of the partial coefficients of competence and concentration.

\section{References}

Bagautdinova, N.G., Panasyuk, M.V., Gafurov, I.R. Wavelet analysis of the territorial socio-economic system dynamics // World Applied Sciences Journal, 27(13), 2013, 62-66.

Berle A. A., Means Gardiner C. The Modern Corporation and Private Property. New York, 1932.

Ford D. Develop your technology strategy. Long Range Planning. 1988. № 21 (5). October.

Hussey D. Strategic Management: From Theory to Implementation. Oxford, 1998.

Maskell P., Larenzen M. The Claster as Market Organizantion. DRUID Working Paper 03-14, 2003. 29 p.

Peter F. Drucker. The Effective Executive, 1967.

Porter M. The Competitive Advantage of Nations: With a New Introduction. N.Y.: The Free Press, Palgrave Tenth Edition, 1998. 855p.

Rosenfeld S.A. Bringing Business Clusters into the Mainstream of Economic Development // European Planning Studies, Nr. 5, 1997. pp. 3-23.

Bagautdinova N.G., Gafurov I.R., Novenkova A.Z. The transformation of region's economic area governed by the development of industrial region // World Applied Sciences Journal, 25(7), 2013, 1113-1117.

Sarkin, A.V., Bagautdinova, N.G., Averianov, B.A. Development of science-intensive strategy in machinery-building company in contemporary Russia// World Applied Sciences Journal, 27(13), 2013. pp. 24-28.

Kirshin I.A. Modeling the long-term trend of accumulation of knowledge. Life Science Journal 2014; 11(6s): 482 - 486.

Ankudinov B., Lebedev O. V. Investment drivers of shareholder value creation in large publicly traded Russian companies // Investment Management and Financial Innovations. - 2014. - 11 (2) . - pp. 77-85.

Ankudinov B., Lebedev O. V. Job insecurity and employees' motivation to engage in professional education // American Journal of Applied Sciences 11 (5): 860-865, 2014. 